ISSN 0258-7122

Bangladesh J. Agril. Res. 34(4) : 683-692, December 2009

\title{
EFFECT OF IRRIGATION ON THE YIELD AND SCAB INFECTION OF POTATO
}

\author{
M. S. ISLAM ${ }^{1}$, M. M. HOSSAIN ${ }^{2}$ \\ MD. SHARIFUL ISLAM ${ }^{3}$ AND M. A. HOSSAIN ${ }^{4}$
}

\begin{abstract}
An experiment was conducted in Jamalpur during the Rabi seasons of 20042005 and 2005-2006 to investigate the yield and scab infection of potato variety Diamant under different irrigation frequencies and quantities. Three irrigation intervals, 7, 12 and 17 days along with three levels of water quantities equaling 50, 100 and $150 \%$ of depleted soil moisture were tested for yield and scab infection of potato tubers. It was observed in 2004-2005 that irrigation interval of 12 days and watering at $100 \%$ depletion of soil moisture produced the highest fresh and total yields of $24.64 \mathrm{t} / \mathrm{ha}$ and $27.56 \mathrm{t} / \mathrm{ha}$, respectively, whereas irrigation interval of 7 days and watering at $150 \%$ of depleted soil moisture produced the lowest fresh and total yields (21.68 t/ha and $25.98 \mathrm{t} / \mathrm{ha}$, respectively). In 2005-2006, irrigation interval of 12 days and watering at $100 \%$ depletion of soil moisture produced the fresh and total yields of $26.27 \mathrm{t} / \mathrm{ha}$ and $27.41 \mathrm{t} / \mathrm{ha}$, respectively, and were not found statistically different from those obtained under water application of $150 \%$ depleted soil moisture and irrigation interval of 12 days. The scab infected tubers were found the highest $4.30 \mathrm{t} / \mathrm{ha}$ in 2004-2005 and 2.97 t/ha in 2005-2006 for water application of 150\% depleted soil moisture and 7 days irrigation intervals. This indicates that scab disease is more susceptible to frequent and over irrigation.
\end{abstract}

Key Words: Irrigation interval, moisture depletion, scab disease.

\section{Introduction}

Potato is an important food crop in the present world. It is high yielder, comparatively low cost, palatable and nutritious. Considering the nutritive value, it is a crop-per-excellence, having carbohydrates in abundance, proteins of superior quality, minerals and fibers in appreciable amounts, vitamin C in sufficient quantity and some B vitamins in high or reasonably good quantity (Ahmed, 1982). The fat content of potato is only $0.4 \%$ compared to $0.7 \%$ in rice and $2.3 \%$ in wheat flour. It also produces considerable dry matter per unit area compared to many other crops. In short, potato is a wholesome food and it provides essential body building substances.

Potato is one of the most sensitive crops to soil water stress and it is recognized as a major constraint to potato production worldwide (Schapendonk

${ }^{1}$ Chief Scientific Officer, Irrigation and Water Management Division, BARI, Joydebpur, Gazipur 1701, ${ }^{4}$ Senior. Scientific Officer, Irrigation and Water Management Division, BARI, Joydebpur, Gazipur 1701, ${ }^{2}$ Senior Scientific Officer, Regional Agril. Res. Station, Rahmatpur, BARI, ${ }^{3}$ Assistant Engineer, BMDA, Rajshahi, Bangladesh. 
et al., 1989). Jamieson (1985) found that the yield of tubers increased 45 to 55 $\mathrm{kg} / \mathrm{ha}$ for each millimeter of water applied.

The scab disease (Streytomyces scabies) can seriously affect the yield, quality and storage of potato (Hooker, 1983). Davis et al. (1974) found that scab infection was likely between 2-5 weeks after tuber initiation. In another study, Davis et al. (1976) found that maintaining high soil moisture levels during initial stages of tuber initiations, it was very difficult to minimize scab levels. Among other probable reasons, irrigation may be a controlling factor for the infection of scab disease of potato. Irrigation interval and quantity can have specific effects on the extent of scab infection. Only a few reports on the effect of irrigation on scab infection of potato are available in Bangladesh. Thus, the present study was undertaken to see the effect of irrigation interval and water quantity on the yield and extent of scab infection of potato variety Diamant.

\section{Materials and Method}

The experiment was conducted during the Rabi seasons of 2004-2005 and 20052006 in Brahmaputra flood plain soil. Texturally, it was sandy loam. The field capacity of the soil was $30 \%$ by weight and the bulk density was $1.5 \mathrm{gm} / \mathrm{cm}^{3}$. The selected crop was potato and the variety was Diamant. The plot size was $3 \mathrm{mx} 3 \mathrm{~m}$. Each treatment was replicated thrice. The soil moisture was allowed to deplete from field capacity for a certain period (as per design of the treatments) and then, irrigation water was applied meeting the certain percentage of depleted soil water. The treatments were arranged in a randomized block design.

$\mathrm{T}_{1}=$ Irrigation at 7 days interval meeting $50 \%$ depleted soil moisture

$\mathrm{T}_{2}=$ Irrigation at 7 days interval meeting $100 \%$ depleted soil moisture

$\mathrm{T}_{3}=$ Irrigation at 7 days interval meeting $150 \%$ depleted soil moisture

$\mathrm{T}_{4}=$ Irrigation at 12 days interval meeting $50 \%$ depleted soil moisture

$\mathrm{T}_{5}=$ Irrigation at 12 days interval meeting $100 \%$ depleted soil moisture

$\mathrm{T}_{6}=$ Irrigation at 12 days interval meeting $150 \%$ depleted soil moisture

$\mathrm{T}_{7}=$ Irrigation at 17 days interval meeting $50 \%$ depleted soil moisture

$\mathrm{T}_{8}=$ Irrigation at 17 days interval meeting $100 \%$ depleted soil moisture

$\mathrm{T}_{9}=$ Irrigation at 17 days interval meeting $150 \%$ depleted soil moisture

The land was prepared and seeds were sown on 05 December 2004 and 08 December 2005. Row to row spacing was $60 \mathrm{~cm}$ and plant to plant spacing, 25 $\mathrm{cm}$. Whole tubers were planted. Furrow method of water application was used in the experiment. Irrigation was applied as per design of the treatments and measured quantity of water was applied to plots. For proper germination of potato seeds, a common irrigation was given to all the treatments on 06 December 2004 and 10 December 2005. Thereafter, the plots were irrigated as 
per treatment design. Soil moisture was monitored at plantation, before each irrigation and at harvest. From the monitored soil moisture, the required depth of water application was determined using the following equation (Michael, 1978):

$I R=\left\{\left(M_{F C}-M_{b}\right) / 100\right\} \times p_{b} \times D$

Where,

$\mathrm{JR}=$ net irrigation requirement $(\mathrm{cm})$;

$\mathrm{M}_{\mathrm{FC}}=$ soil moisture content at field capacity (\% by weight);

$\mathrm{M}_{\mathrm{b}}=$ soil moisture content before irrigation, (\% by weight);

$\mathrm{p}_{\mathrm{b}}=$ soil bulk density $\left(\mathrm{gm} / \mathrm{cm}^{3}\right)$ and

$\mathrm{D}=$ effective root depth $(\mathrm{cm})$.

The net irrigation requirement equaled the net depth of depleted soil moisture (d) as there was no conveyance loss of irrigation water. Effective crop root depth was considered $30 \mathrm{~cm}$. The depth of depleted soil moisture was converted to volume of water in liter by the following relationship:

$V=\{(A \times d) \times 10000\} / 1000$ or $V=10 \times(A \times d)$

Where,

$\mathrm{V}=$ volume of irrigation water (liter), $\mathrm{A}=$ area $\left(\mathrm{m}^{2}\right), \mathrm{d}=$ net depth of irrigation $(\mathrm{cm}), 10000=$ conversion of $\mathrm{m}^{2}$ to $\mathrm{cm}^{2}, 1000=$ conversion of $\mathrm{ml}$ to liter. Since, the water was applied by pipes, the duration of irrigation, $\mathrm{t}$ (in minute), required to replenish the depleted soil water volume was calculated by-

$t=V / q$

Where, $\mathrm{q}$ is the flow rate (liter/minute) of water from the pipe measured before irrigation. Based on the estimated time, water was applied to different treatments using pipe. The volume of water (V) as estimated above was applied for the treatment irrigated at $100 \%$ depletion of soil moisture. Those for the treatments irrigated at $50 \%$ and $150 \%$ depletion of soil moisture were estimated as half and 1.5 times the volume of $100 \%$ depleted water, respectively. Irrigation intervals of 7, 12 and 17 days were maintained. Fertilizers were applied at the rate of $\mathrm{N}_{160} \mathrm{P}_{45}$ $\mathrm{K}_{130} \mathrm{~S}_{20} \mathrm{Zn}_{5} \mathrm{~B}_{1} \mathrm{~kg} / \mathrm{ha}$. Number of stems/hill, plant height, yield of tubers and number and weight of scab affected potato tubers were recorded. The harvested tubers were then checked for scab disease. In addition to yield and number of fresh tubers, the same were also recorded for scab affected tubers. All these parameters were analyzed statistically using computer software, MSTAT.

\section{Results and Discussion}

Results of analyzed data of plant height, stems/hill, number of tubers per 5 plants, weight of tubers per 5 plants, yield of scab affected tubers, fresh and total yields are presented and discussed below: 


\section{Tuber yields as affected by irrigation regimes and intervals}

Table 1 shows that there was no significant effect of irrigation interval and quantity of water applied on total yield of tuber production in 2004-2005. However, the highest yield (27.89 t/ha) was obtained from irrigation interval of 12 days and meeting $100 \%$ of depleted soil moisture. The lowest total yield (25.98 t/ha) was obtained from irrigation applied at 7 days interval and meeting $150 \%$ of depleted soil moisture. This indicates that irrigation upto $150 \%$ depleted soil moisture at 7 days interval did not help attain favourable soil moisture for plants due to excessive moisture content in the root zone of the soil. Again, the fresh yield was found highest (24.64 t/ha) at irrigation interval of 12 days with watering upto $100 \%$ of depleted soil moisture. The same was found lowest (21.68 t/ha) for irrigation interval of 7 days and watering upto 150\% of depleted soil moisture. This indicates that watering upto FC level of soil moisture and irrigation interval of 12 days is the most desirable sequence among the tested irrigation options.

Table 1. Fresh yield, number of infected tubers and weight of infected tubers for different irrigation intervals and quantities applied.

\begin{tabular}{l|l|l|l|l|l|l}
\hline \multirow{2}{*}{ Treatments } & \multicolumn{2}{|c|}{ Fresh yield (t/ha) } & \multicolumn{2}{c|}{$\begin{array}{c}\text { Infected tuber yield } \\
\text { (t/ha) }\end{array}$} & \multicolumn{2}{c}{ Total yield (t/ha) } \\
\cline { 2 - 7 } & $2004-2005$ & $2005-2006$ & $2004-2005$ & $2005-2006$ & $2004-2005$ & $2005-2006$ \\
\hline $\mathrm{T}_{1}$ & 23.53 & 23.11 & 4.10 & 2.54 & 27.63 & 25.65 \\
$\mathrm{~T}_{2}$ & 23.81 & 22.28 & 3.53 & 2.64 & 27.34 & 24.97 \\
$\mathrm{~T}_{3}$ & 21.68 & 20.05 & 4.30 & 2.97 & 25.98 & 23.02 \\
$\mathrm{~T}_{4}$ & 23.34 & 25.23 & 3.63 & 1.19 & 26.97 & 26.42 \\
$\mathrm{~T}_{5}$ & 24.64 & 26.27 & 3.25 & 1.20 & 27.89 & 27.47 \\
$\mathrm{~T}_{6}$ & 23.40 & 26.24 & 3.84 & 1.12 & 27.24 & 27.36 \\
$\mathrm{~T}_{7}$ & 22.82 & 24.88 & 3.42 & 1.28 & 26.24 & 26.16 \\
$\mathrm{~T}_{8}$ & 23.35 & 25.17 & 3.30 & 1.42 & 26.65 & 26.59 \\
$\mathrm{~T}_{9}$ & 23.32 & 25.16 & 3.37 & 2.20 & 26.69 & 27.36 \\
\hline CV & 5.94 & 1.99 & 4.87 & 0.301 & 3.20 & 1.66 \\
LSD & NS & 0.752 & 12.87 & 0.409 & NS & 3.00 \\
\hline
\end{tabular}

In 2005-2006, fresh yield, infected yield and total yield were found to differ significantly under variable quantities of water applied and irrigation intervals. The highest total (27.47 t/ha) and fresh (26.27 t/ha) yields were also obtained from the same irrigation sequence as of the first year. In 2004-2005, the scab infected tuber yield was found lowest (3.25 t/ha) in the treatment $\left(T_{5}\right)$ with irrigation interval of 12 days and watering upto $100 \%$ depletion of soil moisture. Among the selected intervals and water quantities, irrigation at 7 days interval and watering upto $150 \%$ depleted soil moisture produced the highest (4.30 t/ha) quantity of infected tubers. In 2005-2006, the yield of scab infected tubers was 
found highest ( $2.97 \mathrm{t} / \mathrm{ha}$ ) from irrigation interval of 7 days and water application upto $150 \%$ depletion of soil moisture.

Practically, an interval of 7 days with over irrigation (150\% of depleted soil moisture) created aeration problem in crop root zone and enhanced more scab infection. This indicates that both over watering and frequent irrigations affected potato tubers most. So, for the Diamant variety of potato, irrigation interval of 12 days and watering at $100 \%$ depleted soil moisture appeared to be optimal to produce good yield of potato in sandy loam soil. The findings are in agreement with the results obtained by Davis et al.(1974).

\section{Crop characters as influenced by irrigation regimes and intervals}

From Table 2, it reveals that in 2004-2005, none of the crop characters had significant difference among the treatments. The plant height ranged from 76.8 to $90.0 \mathrm{~cm}$. The number of stems/hill, as seen from the same table, was the highest (4.68) in treatments irrigated at 7 and 17 days intervals with irrigation water applied meeting upto $100 \%$ depletion of soil moisture. The lowest number of stems/hill (3.33) was obtained in treatment irrigated at 7 days interval and watering meeting 50\% depleted soil moisture. In 2005-2006, the plant height ranged from 58.0 to $66.33 \mathrm{~cm}$ somewhat less than that of the previous year. This variation might be due to change in climate between the study years. The plant height and number of stems/hill showed significant difference among the treatments but the others did not. The same trend was also found for the number and weight of tubers per 5 plants.

\section{Tuber size as affected by irrigation interval and regime}

The harvested potato tubers were graded using sieve. The tubers were grouped in three grades. Grade I comprised the tubers of diameter $<28 \mathrm{~mm}$, Grade II comprised tubers of 28 to $45 \mathrm{~mm}$ diameter and Grade III comprised the tubers of 45 to $55 \mathrm{~mm}$ diameter. Usually the Grade II potatoes are the most suitable for marketing because the buyers prefer medium sized potatoes. However, those under Grade III are suitable for commercial products like chips and crackers. It is seen from Table 3 that the maximum number of tubers/plot was found under Grade II for irrigation interval of 12 days and watering upto $100 \%$ of depleted soil moisture, the corresponding weight being $6.41 \mathrm{~kg} / \mathrm{plot}$. All the numbers under Grade II were found to vary significantly among the selected irrigation intervals and water application sequences. Number of tubers under Grade I \& II, and the corresponding weights of tubers were found not to vary significantly among the treatments. This indicates that the selected 12 days interval and 100\% water application level suited best for the production of Grade II potato tubers. 
Table 2 Effect of irrigation regimes and intervals on plant height, stems/hill, number of tubers per 5 plants and weight of tubers per 5 plants.

\begin{tabular}{|c|c|c|c|c|c|c|c|c|}
\hline \multirow{2}{*}{ Treatments } & \multicolumn{2}{|c|}{ Plant height $(\mathrm{cm})$} & \multicolumn{2}{|c|}{ No. of stems/hill } & \multicolumn{2}{|c|}{$\begin{array}{c}\text { No. of tubers/5 } \\
\text { plants }\end{array}$} & \multicolumn{2}{|c|}{$\begin{array}{l}\text { Wt. of tubers /5 } \\
\text { plants (kg) }\end{array}$} \\
\hline & $\begin{array}{l}2004- \\
2005\end{array}$ & $\begin{array}{c}2005- \\
2006 \\
\end{array}$ & $\begin{array}{c}2004- \\
2005 \\
\end{array}$ & $\begin{array}{c}2005- \\
2006\end{array}$ & $\begin{array}{l}2004- \\
2005 \\
\end{array}$ & \begin{tabular}{|c|}
$2005-$ \\
2006 \\
\end{tabular} & $\begin{array}{c}2004- \\
2005\end{array}$ & \begin{tabular}{|c|}
$2005-$ \\
2006 \\
\end{tabular} \\
\hline $\mathrm{T}_{1}$ & 83.3 & 63.00 & 3.33 & 6.67 & 35 & 41 & 1.55 & 1.77 \\
\hline $\mathrm{T}_{2}$ & 83.3 & 58.00 & 4.68 & 6.33 & 36 & 46 & 1.62 & 1.91 \\
\hline $\mathrm{T}_{3}$ & 80.0 & 61.30 & 3.68 & 6.00 & 33 & 44 & 1.63 & 1.72 \\
\hline $\mathrm{T}_{4}$ & 90.0 & 60.67 & 3.68 & 6.00 & 35 & 48 & 1.58 & 2.01 \\
\hline $\mathrm{T}_{5}$ & 80.0 & 66.33 & 3.68 & 6.33 & 39 & 44 & 1.60 & 1.84 \\
\hline $\mathrm{T}_{6}$ & 83.3 & 64.67 & 4.43 & 6.33 & 37 & 41 & 1.67 & 1.74 \\
\hline $\mathrm{T}_{7}$ & 80.0 & 65.67 & 4.43 & 5.33 & 36 & 47 & 1.45 & 1.94 \\
\hline $\mathrm{T}_{8}$ & 76.8 & 65.67 & 4.68 & 6.33 & 37 & 50 & 1.45 & 2.07 \\
\hline $\mathrm{T}_{9}$ & 86.8 & 59.67 & 4.00 & 6.67 & 39 & 42 & 1.44 & 1.74 \\
\hline $\mathrm{CV}$ & 14.46 & 6.10 & 18.84 & 8.47 & 16.03 & 7.96 & 10.97 & 12.77 \\
\hline LSD & NS & 6.64 & NS & 0.913 & NS & NS & NS & NS \\
\hline
\end{tabular}

From Table 4, it appears that unlike the findings of 2004-2005, potato tubers under Grade I, II and III and their weights per plot were found to vary significantly among the levels of water application and irrigation intervals. The highest number of Grade I potato tubers (124 per plot) and weight (1.0 kg/plot)

Table 3. Number and weight of graded tubers per plot as affected by irrigation sequence in 2004-2005.

\begin{tabular}{l|l|l|l|l|l|l}
\hline Treatments & $\begin{array}{c}\text { No. of } \\
\text { tubers } \\
<28 \mathrm{~mm} \\
\text { dia. }\end{array}$ & $\begin{array}{c}\text { Wt. of } \\
\text { tubers } \\
<28 \mathrm{~mm} \\
\text { dia. (kg) }\end{array}$ & $\begin{array}{c}\text { No. of } \\
\text { tubers, 28- } \\
45 \mathrm{~mm} \text { dia. }\end{array}$ & $\begin{array}{c}\text { Wt. of } \\
\text { tubers, 28- } \\
45 \mathrm{~mm} \text { dia. } \\
(\mathrm{kg})\end{array}$ & $\begin{array}{c}\text { No. of } \\
\text { tubers, } \\
45-55 \mathrm{~mm} \\
\text { dia. }\end{array}$ & $\begin{array}{c}\text { Wt. of } \\
\text { tubers, 45- } \\
55 \mathrm{~mm} \\
\text { dia. } \\
(\mathrm{kg})\end{array}$ \\
\hline $\mathrm{T}_{1}$ & 46 & 0.47 & 143 & 4.78 & 159 & 12.45 \\
$\mathrm{~T}_{2}$ & 60 & 0.43 & 163 & 5.55 & 166 & 12.99 \\
$\mathrm{~T}_{3}$ & 73 & 0.65 & 132 & 4.45 & 148 & 12.35 \\
$\mathrm{~T}_{4}$ & 59 & 0.56 & 179 & 6.10 & 159 & 12.51 \\
$\mathrm{~T}_{5}$ & 60 & 0.56 & 195 & 6.41 & 156 & 12.47 \\
$\mathrm{~T}_{6}$ & 65 & 0.63 & 150 & 5.15 & 138 & 11.40 \\
$\mathrm{~T}_{7}$ & 53 & 0.47 & 178 & 6.22 & 138 & 11.30 \\
$\mathrm{~T}_{8}$ & 59 & 0.57 & 104 & 3.62 & 160 & 12.51 \\
$\mathrm{~T}_{9}$ & 62 & 0.60 & 190 & 6.39 & 145 & 11.40 \\
\hline CV & 21.41 & 17.95 & 19.76 & 25.43 & 15.94 & 13.58 \\
LSD & NS & NS & 54.55 & NS & NS & NS \\
\hline
\end{tabular}


Table 4. Number and weight of graded tubers per plot as affected by irrigation sequence in 2005-2006.

\begin{tabular}{l|l|l|l|l|l|l}
\hline Treatments & $\begin{array}{c}\text { No. of } \\
\text { tubers } \\
<28 \mathrm{~mm}\end{array}$ & $\begin{array}{c}\text { Wt. of } \\
\text { tubers } \\
<28 \mathrm{~mm} \\
(\mathrm{~kg})\end{array}$ & $\begin{array}{c}\text { No. of } \\
\text { tubers, 28- } \\
45 \mathrm{~mm}\end{array}$ & $\begin{array}{c}\text { Wt. of } \\
\text { tubers, 28- } \\
45 \mathrm{~mm} \\
(\mathrm{~kg})\end{array}$ & $\begin{array}{c}\text { No. of } \\
\text { tubers, } \\
45-55 \mathrm{~mm}\end{array}$ & $\begin{array}{c}\text { Wt. of } \\
\text { tubers, 45- } \\
55 \mathrm{~mm} \\
(\mathrm{~kg})\end{array}$ \\
\hline $\mathrm{T}_{1}$ & 124 & 1.00 & 188 & 5.83 & 137 & 10.07 \\
$\mathrm{~T}_{2}$ & 109 & 0.97 & 147 & 4.77 & 143 & 10.37 \\
$\mathrm{~T}_{3}$ & 102 & 1.00 & 157 & 4.67 & 152 & 11.33 \\
$\mathrm{~T}_{4}$ & 97 & 0.80 & 167 & 5.27 & 158 & 12.53 \\
$\mathrm{~T}_{5}$ & 101 & 0.90 & 189 & 6.20 & 196 & 12.33 \\
$\mathrm{~T}_{6}$ & 87 & 0.73 & 140 & 4.03 & 162 & 13.17 \\
$\mathrm{~T}_{7}$ & 77 & 0.63 & 162 & 5.10 & 155 & 11.67 \\
$\mathrm{~T}_{8}$ & 93 & 0.80 & 134 & 3.80 & 152 & 11.60 \\
$\mathrm{~T}_{9}$ & 92 & 0.70 & 123 & 3.80 & 115 & 12.13 \\
\hline $\mathrm{CV}$ & 14.19 & 21.20 & 13.74 & 12.69 & 12.38 & 6.39 \\
$\mathrm{LSD}$ & 24.12 & 0.305 & 37.20 & 1.06 & 32.14 & 1.29 \\
\hline
\end{tabular}

were found for 7 days irrigation interval with water application upto $50 \%$ of depleted soil moisture. The numbers and weights of tubers under Grade II were found 189 per plot and $6.02 \mathrm{~kg} /$ plot and those under Grade III were 196 per plot and $13.17 \mathrm{~kg} / \mathrm{plot}$.

\section{Water use by plants}

As mentioned earlier, amount of irrigation water was applied upto 50, 100 and $150 \%$ of the moisture depleted from FC of soil. The amount of water needed to apply was measured using the equation mentioned under materials and method section. Seasonal water use was estimated by-

$W_{s}=I_{w}+R_{e} \pm \Delta_{s}$

Where, $\mathrm{W}_{\mathrm{s}}$ is the water use, $\mathrm{I}_{\mathrm{w}}$ is irrigation water, Re is effective rainfall and $\Delta \mathrm{s}$ is the residual soil moisture (i.e., change in stored soil moisture) for the whole season for a particular treatment. All are in millimeter (mm).

During the experimentation, the plants received no effective rainfall. Residual soil water was determined from the difference of soil moisture at planting and harvest. Irrigation water comprised the water needed to replenish the soil as per design of the treatments. So, in the above equation, only the term "effective rainfall" was considered nil in the estimation of water used by the treatments. Treatment-wise irrigation water (1W), residual soil water (RSW) and seasonal water use or the total water (TW) are shown in Fig. 1 and 2 for 20042005 and 2005-2006, respectively.

In 2004-2005, the average soil moisture at plantation for all the treatments was $20.97 \%$ and those at harvest for $T_{1}, T_{2}, T_{3}, T_{4}, T_{5}, T_{6}, T_{7}, T_{8}$ and $T_{9}$ were 
$17.70,18.52,18.65,18.15,18.97,19.05,18.17,18.89$, and 20.24\%, respectively. In $2005-2006$, the average soil moisture at plantation was $20.05 \%$ for all the treatments and those at harvest were 16.04, 16.67, 18.67, 16.24, 17.10, 18.21, 18.67, 19.25 and $20.22 \%$ for the treatments, $T_{1}, T_{2}, T_{3}, T_{4}, T_{5}, T_{6}, T_{7}, T_{8}$ and $T_{9}$, respectively. An overall view of the experimental set up, scab infested potato and some fresh potato are shown in Fig. 3, 4 and 5, respectively.

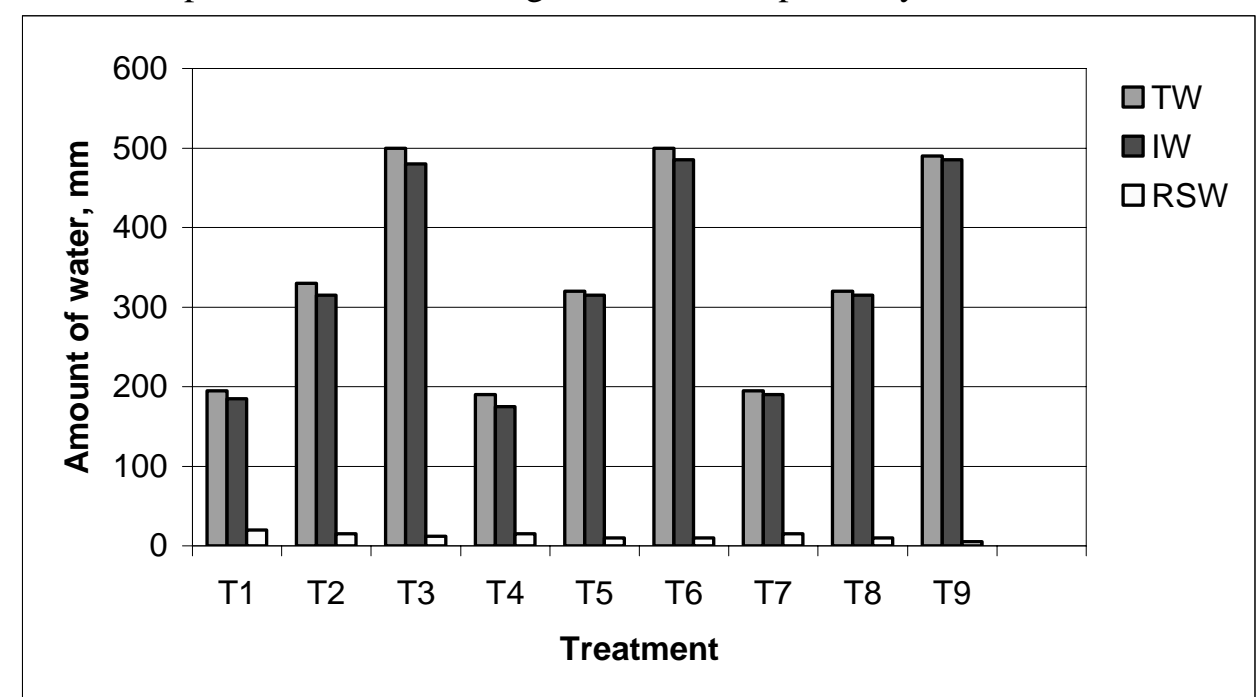

1. Water use by potato plants in 2004-2005

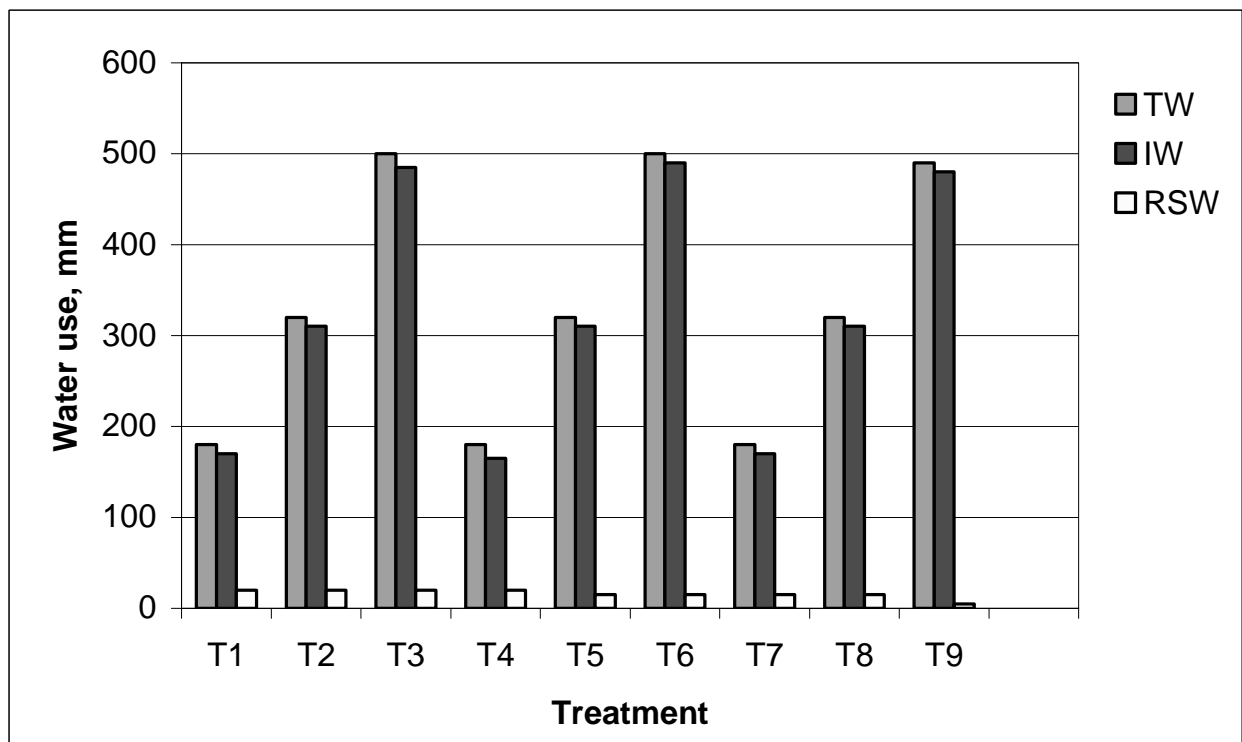

2. Water use by potato plants in 2004-2005 


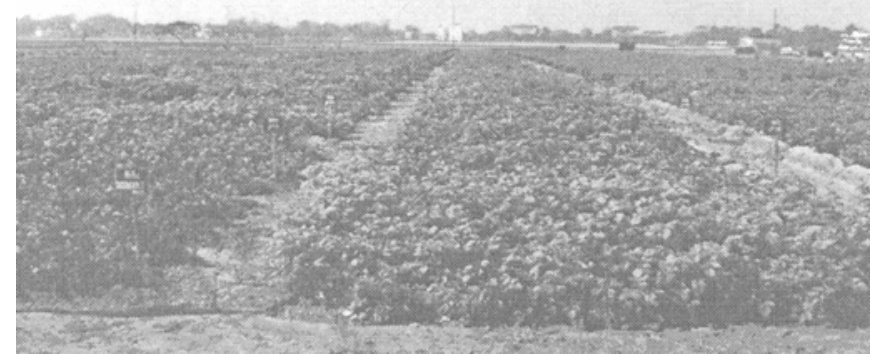

Fig. 3. Potato plants in the experimental plot.

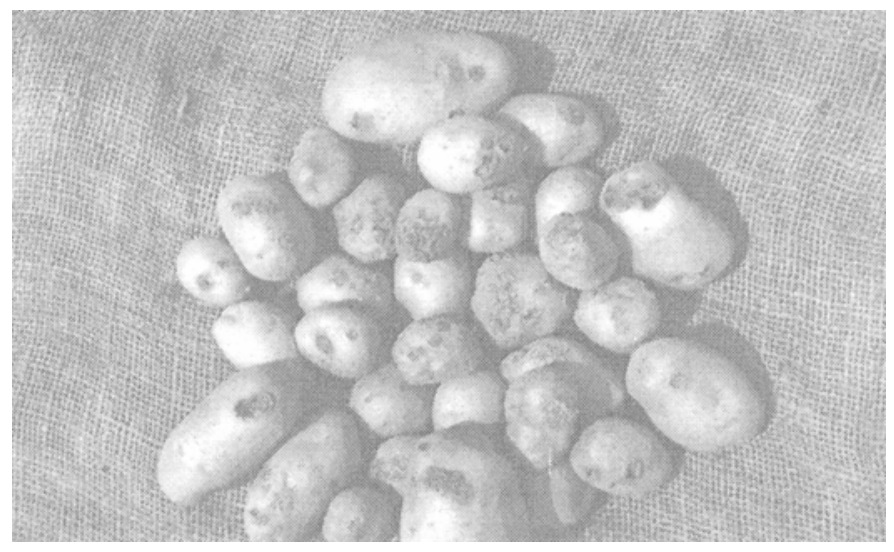

Fig. 4. Scab infected potato tubers.

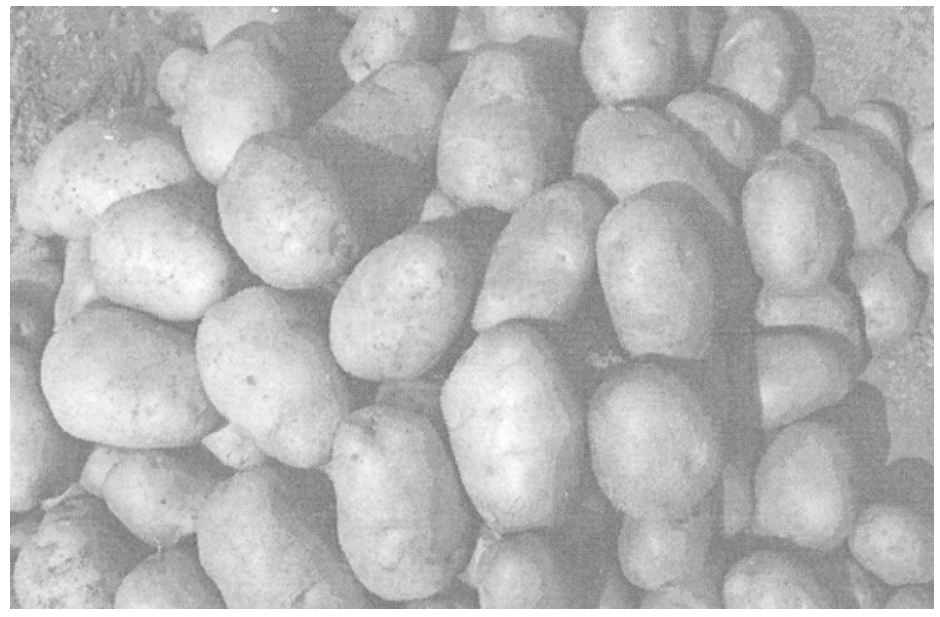

Fig. 5. Scab free potato tubers. 


\section{Conclusion}

Frequent irrigation accelerates scab infection of potato tubers. The rate of infection also varies with the quantity of water used by the plants. Irrigation amount up to field capacity and 12 days interval appear optimal for potato production in sandy loam soil.

\section{References}

Ahmed, K.U. 1982. Gardeners book of production and nutrition. Vol. 1. pp. 120-129.

Davis, J.R., G.M. McMaster, R.H. Callihan, J.G. Garner and R.E. McDole. 1974. The relationship of irrigation timing and soil treatments to control potato scab. Phytopatholgy 66: 1404-1410

Davis, J.R., G.M. McMaster, R.H. Callihan, E.H. Nissley and J.J. Pavek. 1976. Influence of soil moisture and fungicide treatments on common scab and mineral content of potatoes. Phytopathology 66: $1236-1241$.

Hooker, W.J. 1983. Compendium of potato diseases. American Pathological Society. Minnesota, USA.

Jamieson, P.D. 1985. Irrigation response of potatoes. Special publication. Agronomy Society of New Zealand 3: 158-161.

Michael, A.M. 1978. Irrigation Theory and Practice. Vikash Publishing House Pvt. Limited. 576, Masjid Road, Jangpura, New Delhi 110014, India.

Schapendonk, A.H.C.M., C.J.T. Spitters and P.J. Groot. 1989. Effects of water stress on photosynthesis and chlorophyll fluorescence of five potato cultivars. Potato Res. 32: 17-32. 